\title{
BIO-ETHANOL APPLICATION AS AN ALTERNATIVE FUEL IN FARM MACHINE
}

\author{
Sehsah, M. E*, E.B. Belal**, R.R. Abu shieshaa*** and A. Ellawaty****
}

\section{ABSTRACT}

The current research is the second part from study of the bioethanol production under local conditions. The experiments were carried out at the agricultural engineering laboratory, Agricultural Engineering Department, faculty of Agriculture, Kafr El Sheikh University. The experimental aimed to investigate of the possibility to use an alternative fuel for gasoline engine by using various ratios from bioethanol and gasoline. The bioethanol was produced after microbial pre-treatment for starcheous liquid of potato wastes and subsequent fermentation with Saccharomyces cerevisae under laboratory conditions. The blend fuel E10, E30 and E60 were prepared and used at three throttle fuel positions .The engine model Mikuni $13.5 \mathrm{KW}$ at the maximum rotational speed 3600 rpm tested under different blend fuel. The result showed that the Gasoline with octane $80 \mathrm{Nr}$. gave the highest values of treatments for piston sprayer pump and gasoline engine compared to the E10, E30 and E60 of fuel blend, respectively. The engine break horse power at the second fuel throttle position and with load of engine were $6.9 \mathrm{KW}, 6.8$ $\mathrm{KW}$ and $6.9 \mathrm{KW}$ for the fuel blend E10, E30 and the gasoline Octane 80. The fuel blend E10 and E30 gave no significant different compared with the gasoline Octane 80 fuel on the effect of the rotational speed under all treatment conditions. The operating of the engine with load gave the highest values of noise of the engine compared to operate the engine without load for all blend fuel and Gasoline fuel tests. The blend fuel E60 gave the low values of sound level compared to the other blend fuel and Gasoline fuel. On the other hand, the effect of the increasing of throttle position from first to third position those mean the increasing of fuel flow rate tends to increase the sound level.

\footnotetext{
*Associate Prof, Agric. Eng. Dept., Fac. Of Agric., Kafr EL Sheikh Univ. Egypt. **Prof.Dr. Microbiolog Dev. Botany . Dept., Fac. Of Agric., Kafr EL Sheikh Univ. Egypt. ***head of research Prof.Dr. Agric. Eng. At. Eng. Res. Institute. Dokki., giza. Egypt. ****Post- graduate student, Agric. Eng. Dept., Fac. Of Agric., Kafr EL Sheikh Univ. Egypt.
} 
The lower values of noise pollution of the engine were $68.1 \mathrm{~dB}, 78.8 \mathrm{~dB}$ and $81.7 \mathrm{~dB}$ for the fuel blend E60 with load at first, second and third fuel throttle position respectively.

Keywords: Biofuel, bioethanol and piston sprayer pump.

\section{INTRODUCTION}

$\mathrm{W}$

orld production of biofuels is dominated by three countries or regions: the US (43\%), Brazil (32\%) and, less so, the European Union (15\%) Baylis(2008). This will continue to be the case, not only because of respective government policies on biofuels addressing, to various degrees, climate change mitigation, energy security and rural development, but also because of the huge areas of productive land

which are needed to provide biomass feedstocks for any significant biofuel production. Also, conflicts with food and ecosystems are encouraging research into algal feedstocks, in which land-use, at least, will not be an issue. Overall, the need for sustainable sources of biofuel feedstocks has been repeatedly emphasized Gallagher, (2008). Licht, (2006) showed that there's enough alcohol in one year's yield of an acre of potatoes to drive the machinery necessary to cultivate the fields for a hundred years. However, fossil fuels were predominantly used for automobile transportation throughout the last century, obviously due to their lower production cost. As an automotive fuel, hydrous ethanol can be used as a substitute for gasoline in dedicated engines. Anhydrous ethanol, on the other hand, is an effective octane booster when mixed in blends of 5 to $30 \%$ with no engine modification requirement. Mabee, (2007) showed that Brazilian gasoline has a legal alcohol content requirement ranging from $20-25 \%$ according to renewable fuel standards. Most vehicles are being run on E20 or E22, but sales of flex-fuel vehicles capable of operating on E85 blends are strong. Baiju et al. (2009) used methyl and ethyl ester of Karanja oil to run CI engine. They observed good engine performance with reduced emissions of $\mathrm{HC}$ and Smoke.Solomon et al., (2007) throughout Europe for use in spirit lamps. 
A few years later, Henry Ford built his first automobile with an engine that could run on ethanol. In 1908, Ford unveiled his Model T engine equipped with carburetors that could be adjusted to use alcohol, gasoline or a mixture of both fuels. Farrell et al., (2006), Granda Cesar et al., (2007), Kim and Dale, (2005) studied the reason may be that such assessments are generally related to the net energy value (defined as difference in the energy content of ethanol and co-products with the fossil fuel inputs) and to ethanol production routes including the type of raw materials and technologies applied. The "greenness" of a biofuel like ethanol is therefore highly dependent upon the efficiency of all stages in the process from raw material to the end use of product and its avoided use of fossil fuels. While corn ethanol is claimed to have negative energy content or slightly positive value, environmental benefits of cellulosic ethanol cannot be refuted as the corresponding estimated net energy is rather high. The alcohols such as methanol $\left(\mathrm{CH}_{3} \mathrm{OH}\right)$, ethanol $\left(\mathrm{C}_{2} \mathrm{H}_{5} \mathrm{OH}\right)$, propanol $\left(\mathrm{C}_{3} \mathrm{H}_{7} \mathrm{OH}\right)$, and butanol $\left(\mathrm{C}_{4} \mathrm{H}_{9} \mathrm{OH}\right)$ can be used as alternate motor fuels. The combustion heats of alcohols are lower than those of hydrocarbons due to higher oxygen contents. Practically, any of the organic molecules of the alcohol family can be used as a fuel. However, only methanol and ethanol fuels are technically and economically suitable for internal combustion engines (ICEs) Bala (2005). Ethanol has been used in Germany and France as early as 1894 by the then incipient industry of internal combustion engines. Brazil has utilized ethanol as a fuel since 1925. By that time, the production of ethanol was 70 times larger than the production and consumption of petrol. Currently, ethanol is produced from sugar beets and from molasses. A typical yield is 72.5 liters of ethanol per ton of sugar cane. Modern crops yield 60 tons of sugar cane per hectare of land. Production of ethanol from biomass is one way to reduce both the consumption of crude oil and environmental pollution Lang et al., (2001). The use of ethanol and gasoline mixture (gasohol) as an alternative motor fuel has been steadily increasing in the world for a number of reasons by Demirbas (2005). For a fuel to meet the $10 \%$ criterion in the short term, gasoline and diesel vehicles now on the 
road must be able to use it. Only four fuels fail the test. In the long term, one can assume that enough cars can be on the road to handle the non-oil fuel or fuels chosen; no fundamental technical barriers exist. LPG and natural gas are already used fairly extensively in some markets, the former especially in the Netherlands and Italy and the latter in New Zealand and Argentina. Alcohols can now serve as gasoline additives, including up to $20 \%$ ethanol with no changes but replacement of rubber parts in older vehicles (new vehicles already are adapted). Highpercentage alcohol blends can go into FFVs without major problems and they can be used in dedicated vehicles, as has been shown by extensive tests in the United States and large-scale use in Brazil IEA (1999).

\section{OBJECTIVES}

The main objective of the current research is the applicability of bioethanol fuel that produced from waste crops to operate the sprayer engine under Egyptian condition. As well as operating the engine of sprayer by making the different blend bioethanol fuel with Gasoline fuel under laboratory conditions.

\section{MATRIAL AND METHODS}

\section{Laboratory unit system for the alternative bio-fuel}

Figure 1 showed the laboratory system that used to test the bioethanol fuel at different blend fuel. The laboratory system was constructed in the laboratory of Agriculture Engineering Department, Faculty of Agriculture, Kafr El Sheikh Egypt to test the bio-ethanol alternative fuel. The system consisted of the bio-ethanol reactor, two fuel tanks for ethanol and benzene, water pump, pressure manometer, flow-rate meter, valves and gasoline spark ignition engine. Gasoline engine model Mikuni was used to test the ability of applying the produced ethanol from the potato wastes. As well as, test the performance of gasoline engine at different ratios' of Bio-ethanol to operate the pump in sprayer machine under laboratory conditions. The engine model Mikuni 13.5 KW at the maximum rotational speed $3600 \mathrm{rpm}$ tested under different blend fuel. 

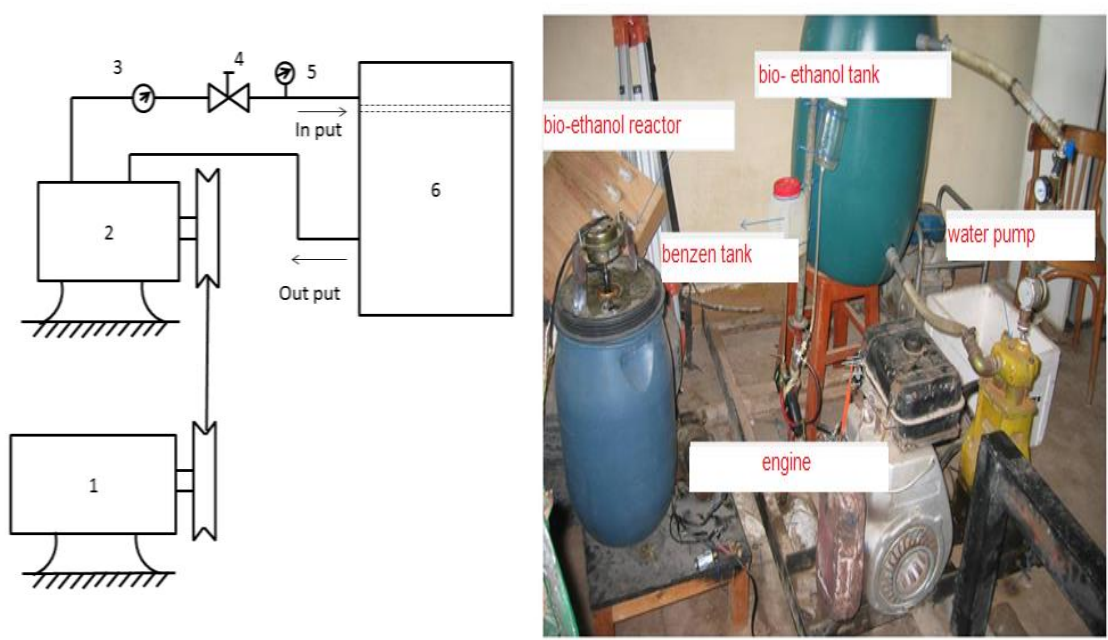

1- Gasoline engine.

2- Piston pump.

3- Flow meter.

4- Valve.

5- Anemometer.

6-Water tank.

Fig. 1: The laboratory unit system for the alternative bio-fuel in Spark ignition engine.

The Digital tachometer Laser HP-2234C was used to measure the rotational speed of engine and the rotational speed of the pump in the sprayer. The multi-function environment instrument with microphone was used to measure the noise of the gasoline engine under all treatment conditions. The noise test of gasoline engine under different treatment conditions was done by the NASHA recommendations (sehsah, et. al., 2010). The distance of about from the exhaust pipe of the engine was 7.5 $\mathrm{m}$ and at the height of $1.2 \mathrm{~m}$.

\section{Procedures}

The bio-ethanol that produced from the potato's wests was mixed with gasoline in different percentage. To obtain the different ratios of bio-fuel E10 E30 and E60, the 10\% ethanol mixed with 90\% gasoline, 30\% ethanol mixed with $70 \%$ gasoline and last one $60 \%$ ethanol mixed with $40 \%$ gasoline respectively.

Before operating the engine, the throttle valve was adjusted at the proper position of the engine to obtain the three different various positions (first, 
second and third position) that regulated at circular plate. The gasoline with octane $80 \mathrm{Nr}$. was used as a control fuel at three different throttle valve positions. As well as, the E10, E30 and E60 were used at the above three throttle valve positions. The rotational speeds were measured under all treatment conditions for the operating of the Gasoline engine. The engine was used to operate the piston pump at the different positions of the throttle conditions as a load on the engine. The pressure of the piston pump was measured at different speeds and different fuel mixing ratios (E10, E30, and E60). Also, the values of the piston pump operating pressure were measured for control fuel (Gasoline 80 Octane $\mathrm{Nr}$.). Previous measurements of the speed of the engine, fuel consumption rate of the engine and the knowledge of the calorific value of the fuel used to calculate the operating power of the engine. That's where the assuming calorific value of different fuel ratios were $444000 \mathrm{~kJ} / \mathrm{kg}, 43470 \mathrm{~kJ} /$ $\mathrm{kg}, 40510 \mathrm{~kJ} / \mathrm{kg}$, and $35760 \mathrm{~kJ} / \mathrm{kg}$ for the gasoline 80, E10, E30 and E60 respectively Thummadetsak (2008).

The power was calculated with load and without load according the following formula:

$$
\mathbf{P b}=\mathbf{P i} * \eta \mathbf{m}
$$

Whereas:

Пm Mechanical efficiency, \% (85\%, assumed Srivastava, 1993)

$\mathrm{Pb} \quad$ Brake power, $\mathrm{kW}$

$\mathrm{Pi} \quad$ Indicate Power, $\mathrm{kW}$

$$
\mathbf{P i}=\eta \mathbf{t h} * \mathbf{P f}
$$

Whereas:

Пth Thermal Efficiency, \% (30\%, assumed Srivastava, 1993)

$\mathrm{Pi}$ Indicated Power, $\mathrm{kW}$

Pf Fuel power, KW

$$
\text { Pf }=\mathbf{C V} * \frac{\mathbf{m f}}{\text { const } \ldots \ldots \ldots \ldots}
$$

Whereas:

Pf Fuel power, KW

$\mathrm{mf}$ The amount of fuel consumed, $\mathrm{kg}$

$\mathrm{CV}$ Calorific value of the fuel, $\mathrm{kJ} / \mathrm{kg}$

$$
\mathbf{m f}=\boldsymbol{\rho} * \mathbf{c f}
$$


Whereas:

mf The amount of fuel consumed, $\mathrm{kg}$

$\rho \quad$ The density of the fuel, $\mathrm{Kg} / \mathrm{m} 3$ (for different fuel mixing ratios, gasoline 80, E10, E30 and E60)

cf Fuel consumption, $1 \mathrm{~min}^{-1}$

Torque is calculated from the equation:

$$
\mathbf{P b}=\frac{2 \pi \mathbf{N T}}{\text { const }} \ldots \ldots \ldots
$$

Whereas:

$\mathrm{Pb} \quad$ Brake power, $\mathrm{kW}$

N Rotational speed, r.p.m

$\mathrm{T}$ Torque, $\mathrm{Nm}$

\section{RESULTS AND DISCUSSION}

\section{Evaluation of the performance of Gasoline SI engine}

Figure 2 illustrate the effect of fuel mixing ratios, throttle position with and without load on the rotation speed of gasoline engine. It is clearly that, the engine rotation speed decreases when the ethanol was added to the Gasoline fuel Oct. Nr. 80 with and without load. However, the highest values of rotational speeds for Octane 80 with no load were 1785 rpm, $2307 \mathrm{rpm}$ and $2407 \mathrm{rpm}$ at first, second and third fuel throttle position respectively. As well as, the operating of the engine with load gave the same trend in the above mentioned conditions. The increasing of the ethanol percentage in the blend fuel tends to decrease the rotational speed. The lower values of rotational speed of the engine were $1084 \mathrm{rpm}$, $1857 \mathrm{rpm}$ and $2275 \mathrm{rpm}$ for the fuel blend E60 with load at first, second and third fuel throttle position respectively. Generally, the operating of the engine with load gave the lowest values of rotational speeds of the engine compared to operate the engine without load. On the other hand, the fuel blend E10 and E30 gave no significant different compared with the gasoline Octane 80 fuel on the effect of the rotational speed under all treatment conditions. The rotational speeds at the second fuel throttle position and without load of engine were 2218, 2111 and 2281 for the fuel blend E10, E30 and the gasoline Octane 80. As well as, the above mentioned result was found at third fuel throttle position under operating conditions of the engine with and without load. The rotational speeds at 
the second fuel throttle position and with load of engine were 2251 r.p.m, 2224 r.p.m and 2307 r.p.m for the fuel blend E10, E30 and the gasoline Octane 80.

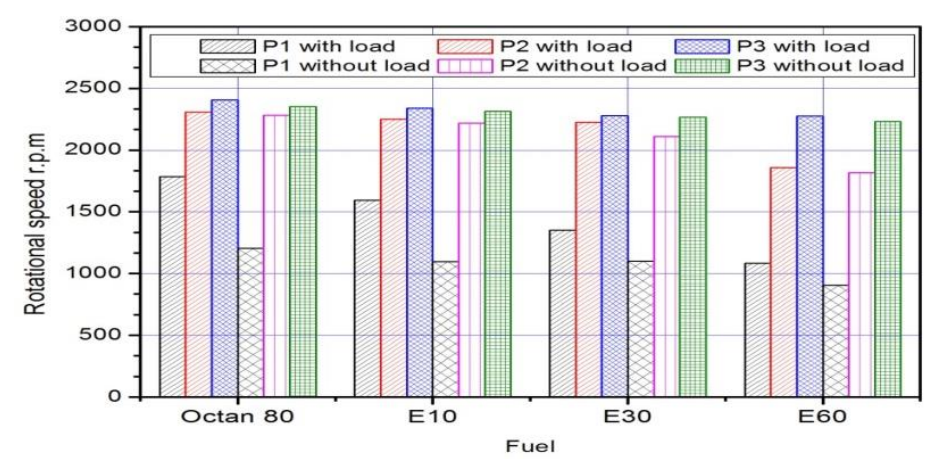

Fig. 2: Effect of blend fuel, position of throttle and the load content on the rotational speed of gasoline engine.

\section{Evaluation of the power Engine operating at different blend fuel}

Figure 3 illustrated that the effect of fuel mixing ratios (blend fuel), throttle position with and without load on the break horse power of gasoline engine. It is clearly that, the engine break horse power decreases when the bio-ethanol was added to the Gasoline fuel Oct. Nr. 80 under operation conditions with and without load. However, the highest values of Engine break horse power for the fuel with Octane Nr. 80 without load were $5.3 \mathrm{KW}, 7.2 \mathrm{KW}$ and $7.9 \mathrm{KW}$ at first, second and third fuel throttle position respectively. As well as, the operating of the engine with load gave the same trend in the above mentioned conditions. The increasing of the bio-ethanol percentage in the blend fuel tends to decrease the engine break horse power. The lower values of break horse power of the engine were $4.5 \mathrm{KW}, 6.3 \mathrm{KW}$ and $6.9 \mathrm{KW}$ for the fuel blend E60 with load at first, second and third fuel throttle position respectively. The above results may be due to the increasing of the fuel consumption from first to third throttle position for octane Nr.80 compared with blend fuel E60. On the other hand, the fuel blend E10 and E30 gave no significant different compared with the gasoline Octane 80 fuel on the effect of the break horse power under all treatment conditions. Therefore, the fuel consumption for both blend fuel E10 and E30 was no different under without load conditions. The engine break horse power at the second fuel throttle position and without load operation conditions were $7.2 \mathrm{KW}, 6.9$ 
KW and 7.2 KW for the fuel blend E10, E30 and the gasoline Octane 80. As well as, the above mentioned result was found at third fuel throttle position under operating conditions of the engine with and without load. The engine break horse power at the second fuel throttle position and with load of engine were $6.9 \mathrm{KW}, 6.8 \mathrm{KW}$ and $6.9 \mathrm{KW}$ for the fuel blend E10, E30 and the gasoline Octane 80.

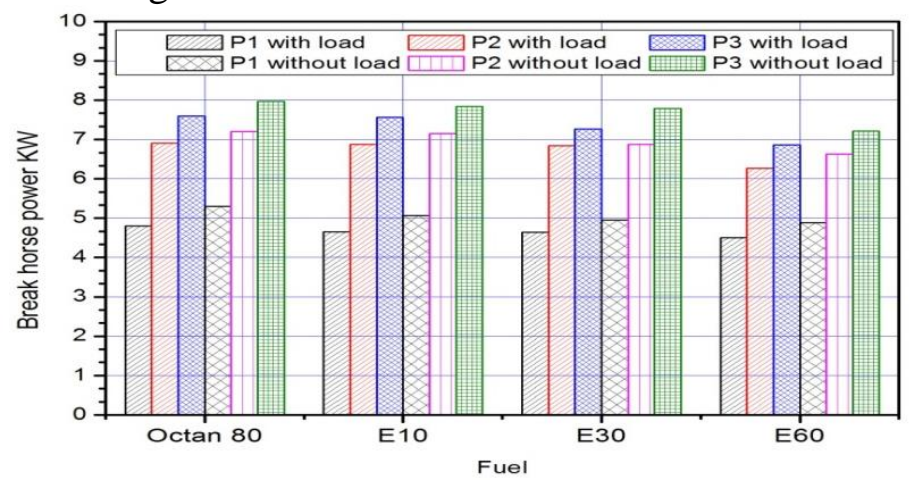

Fig. 3: Effect of blend fuel, position of throttle and the load content on break horse power of gasoline engine.

Figure 4 Shows the effect of blend fuel and throttle position on water sprayer pump rotational speed. It is clear that the sprayer pump of throttle position from first to third increases the rotational speed from 344 r.p.m to 672 r.p.m, 314 r.p.m to 661 r.p.m, 314 r.p.m to 647 r.p.m and 258 r.p.m to 638 r.p.m for Octane 80, E10, E30 and E60 respectively. It is obvious that, the highest rotational speed of 672 r.p.m was recorded by using Octane 80 fuel and throttle position 3. However, the minimum value of 258 r.p.m was obtained by using ethanol blended fuel E60 and at first throttle position.

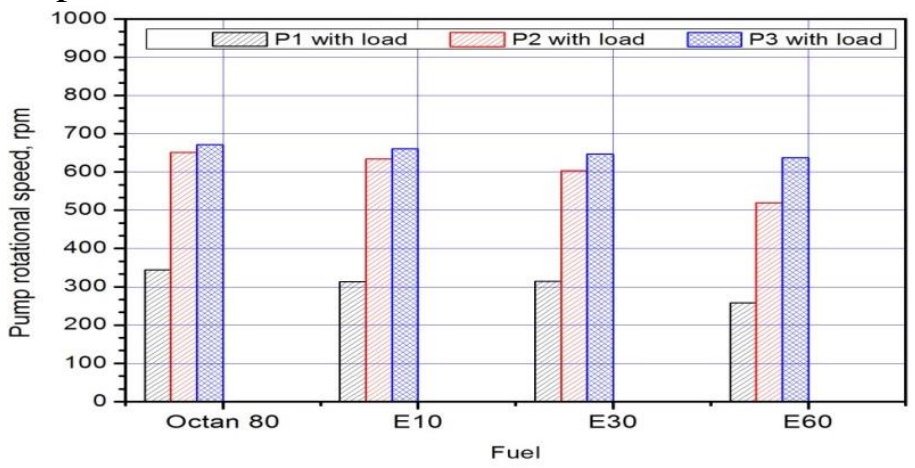

Figure 4: Effect of type of fuel and position of throttle content on rotational speed of piston sprayer pump. 


\section{Noise test of gasoline engine}

Figure 5 illustrated that the effect of fuel mixing ratios, throttle position with and without load on noise pollution. It is clearly that, the noise pollution decreases when the bio-ethanol percentage increased in the Gasoline fuel Oct. Nr. 80 under with and without load conditions. However, the highest values of noise pollution for Octane 80 with load were $75.7 \mathrm{~dB}, 85.7 \mathrm{~dB}$ and $87.0 \mathrm{~dB}$ at first, second and third fuel throttle position respectively. The lower values of noise pollution of the engine were $68.1 \mathrm{~dB}, 78.8 \mathrm{~dB}$ and $81.7 \mathrm{~dB}$ for the fuel blend E60 with load at first, second and third fuel throttle position respectively. Generally, the operating of the engine with load gave the highest values of noise of the engine compared to operate the engine without load. On the other hand, the effect of the increasing of throttle position from first to third position those mean the increasing of fuel flow rate tends to increase the sound level.

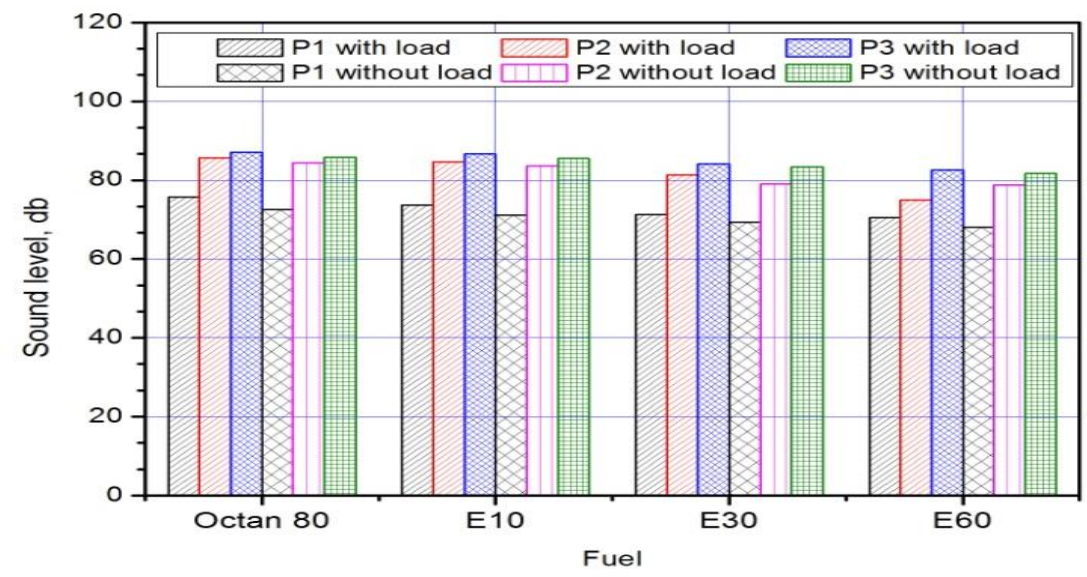

Fig. 5: The effect of blend fuel, position of throttle and the load content on the noise of gasoline engine.

\section{CONCLUSIONS}

The result showed that it may able to apply the bioethanol as an alternative fuel in farm machine such as the engine of the sprayer. The lower values of break horse power of the engine were $4.5 \mathrm{KW}, 6.3 \mathrm{KW}$ and $6.9 \mathrm{KW}$ for the fuel blend E60 with load at first, second and third fuel throttle position respectively. The above results may be due to the 
increasing of the fuel consumption from first to third throttle position for octane Nr.80 compared with blend fuel E60. On the other hand, the fuel blend E10 and E30 gave no significant different compared with the gasoline Octane 80 fuel on the effect of the break horse power under all treatment conditions. Therefore, the fuel consumption for both blend fuel E10 and E30 was no different under without load conditions. The engine break horse power at the second fuel throttle position and with load of engine were $6.9 \mathrm{KW}, 6.8 \mathrm{KW}$ and $6.9 \mathrm{KW}$ for the fuel blend E10, E30 and the gasoline Octane 80 .. The operating of the engine with load gave the lowest values of rotational speeds of the engine compared to operate the engine without load. The above mentioned result was found at third fuel throttle position under operating conditions of the engine with and without load. . The lower values of noise pollution of the engine were $68.1 \mathrm{~dB}, 78.8 \mathrm{~dB}$ and $81.7 \mathrm{~dB}$ for the fuel blend E60 with load at first, second and third fuel throttle position respectively. The fuel blend E10 and E30 gave no significant different compared with the gasoline Octane 80 fuel on the effect of the rotational speed under all treatment conditions.

\section{REFERENCES}

Baiju, B., M. K Naik, and L. M. Das. (2009). A comparative evaluation ocompression ignition characteristics using methyl and ethyl esters of karanja oil. Renewable Energy 34(6): 1616-1621.

Bala, B. K. (2005). Studies on biodiesels from transformation of vegetable oils for diesel engines. Energy Edu. Sci. Technol. 15:1-43.

Baylis, A. D. (2008). Biofuels: what impact on crop protection and seeds now? Part 1: Current status of biofuels and crop feedstocks. Outlooks on Pest Management, 19(5), 217-9. 
Demirbas, A. (2005). Bioethanol from cellulosic materials: A renewable motor fuel from biomass. Energy Sources 27:327-337.

Farrell, A. E., (2006). Ethanol can contribute to energy and environmental goals. Science 311: 506-508.

Gallagher, E. (2008). Report of the Gallagher Review of the indirect effects of biofuel production. UK Renewable Fuels Agency: St Leonards-on-Sea, UK.

Granda Cesar B., (2007). Sustainable liquid biofuels and their environmental impact. Environmental Progress 26: 233-250.

IEA. (1999). Automotive fuels for the future. The Search for Alternatives. Inter National Energy Agency.

Kim, S., and Dale, B. E., (2005). Environmental aspects of ethanol derived from non-tilled corn grain: non-renewable energy consumption and greenhouse gas emissions. Biomass \& Bioenergy 28: 475-489.

Lang, X., Macdonald, D. G., and Hill, G. A. (2001). Recycle bioreactor for bioethanol production from wheat starch. II. Fermentation and economics. Energy Sources 23:427-436.

Licht, F.O. (2006). World Ethanol Market: The Outlook to 2015, Tunbridge Wells, Agra Europe Special Report, UK.

Mabee, W. E. (2007). Policy Options to Support Biofuel Production. Pages 329-357. Biofuels.

Sehsah E E, M A Helmy and H M Soror. (2010). Noise test of tow manufactured power tillers during transport on different local road conditions. Int J Agric \& Biol Eng, 3 (4): 19-27. 
Solomon, B. D., (2007). Grain and cellulosic ethanol: History, economics, and energy policy. Biomass \& Bioenergy 31: 416425 .

Srivastava, A. K., Goering, C. E., and Rohrbach., R. P. (1993). Engineering Principles of Agricultural Machines. ASAE Textbook No. 6. St. Joseph, MI: ASAE.

Thummarat, T. (2008). E10, E20, E30 ; Effects on Tailpipe Emissions, Vehicle Performance and Hot Weather Drivability 6'th Asian Petroleum Technology Symposium, Cebu, Philippines.

$$
\begin{aligned}
& \text { الملخص العربيى } \\
& \text { البيو إثانول و تطبيقه كبديل للوقود فى المعدات الزراعية } \\
& \text { السيد عبد المنطلب بلال }
\end{aligned}
$$

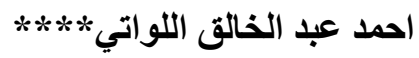

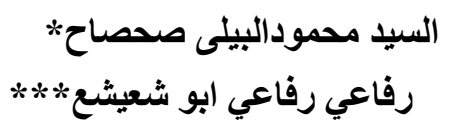

يعتبر استخدام الوقود الحيوي لحل مشكلة الطاقة على مستوى العالم واحدة من أهم نقاط البحثية التى يهتم بها العاملين فى مجال البحث عن بدائل غير تقليدية للوقود ـ فقد لجأت العديد من الدول الى استخدامه كبديل للوقود التقليدي. و نظراً لتفاقم مشكلة الطاقة فى الآونة الآخيرة و كثرة المخلفات فى مصر فقد تم أجراء هذه الدراسة. و تهدف هذه الدراسة التى تم اجراءها بقسم

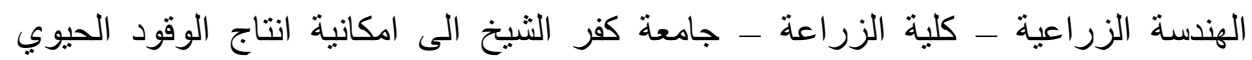

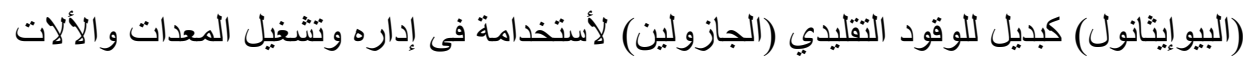
الزراعية.حيث تم إجراء البحث على مرحلتين : المرحله الأولى "مرحلة إنتاج الوقود الحيوي لإئي الدوهي

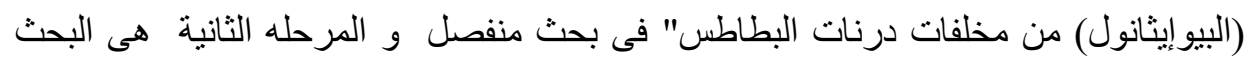
الحالى"مرحلة تطبيق الوقود الحيوي (البيوإثانول) فى إدارة المعدات الزراعية لنسب خلط مختلفه مع الجازولين".

* أستاذ القوى و الالات المساعد ـ قسم الهندة الزراعيةـ كلية الزراعة_جامعة كفر الشيخ- مصر. ** * أستاذ الميكروبيلوجى ـ قسم امراض النباتـ كلية الزراعة_جامعة كفرالشيخ- مصر. **** استاذ الالات والقوى الزراعية ـ معهد بحوث الهندسه الزراعيهـ الاقيـ الجيزهـ مصر. **** طالب دراسات عليا ـ قسم الهندسة الزراعيةـ كلية الزراعة ـ جامعة كفر الثيخ- مصر. 
حيث قد تم استخدام محرك بنزين لادارة طلمبة ماصة كابسة لموتور الرش الثـائع أستعمالة فى في رش الآفات فى مصر ، و تم تشغيل المحرك باستخدام نسب الخلط المختلفة من الجازولين و البيوايثانول و هى E30, E10 و E60 ـ وتم قياس السرعة الدورانية للمحرك بواسطة جهاز قياس السرعة الدورانية و كذلك قياس الضوضناء بواسطة جهاز قياس الضوضناء و حساب القدره الناتجة من المحرك. واظهرت النتائج ان نسب الخلط المختلفة تؤثر على السرعة الدور انية لمحركات المعدات الزر اعية و على القدره الناتجة منها لاداره طلمبة آلة الرش. وكانت

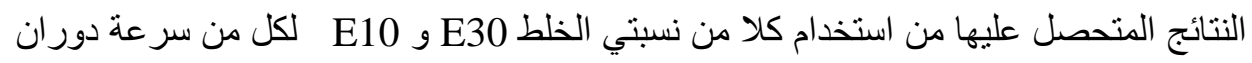
الطلمبة و القدرة الناتجة غير معنوية مقارنة باستخدام الجازولين مما بعنى انة لا يوجد فروق

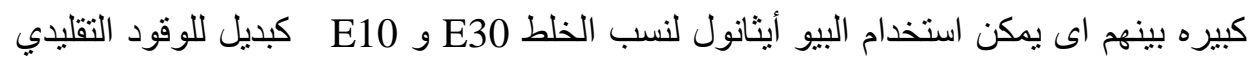
(الجازولين) فى إدارة الات المزرعة. كما وجد أن اقل قيم للضوضاء تم تسجيلها عند استخدام نسبة الخلط E60 و وضع صمام الخانق للوقود فى الوضع الاول لتشغيل المحرك. وكانت اقل قيم للضوضاء عند استخدام نسبة الخلط E60 هى ل

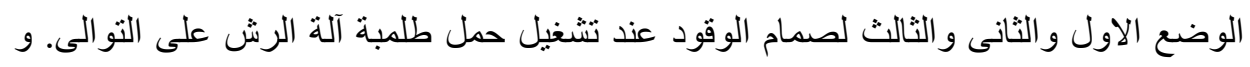

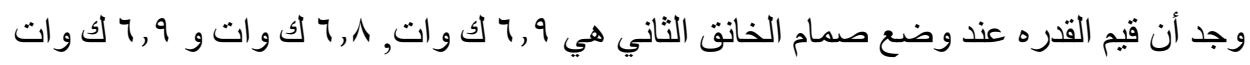
للوقود E10 , E30 و الجازولين فى حالة وجود حمل على التوالى. وكانت قيم السرعة فئ ونى الدور انية للمحرك ال E30 و الجازولين فى حالة وجود حمل عند الوضع الثانى لصمام الخانق على التو الى. 